DOI: https://doi.org/10.31933/dijemss.v2i5

Received: $27^{\text {th }}$ June 2021, Revised: $25^{\text {th }}$ July 2021, Publish: $31^{\text {th }}$ July 2021

\begin{tabular}{|c|c|c|}
\hline PINASTI & $\begin{array}{l}\text { DIJEMSS } \\
\text { DINASTI INTERNATIONAL JOURNAL } \\
\text { OF EDUCATION MANAGEMENT AND } \\
\text { SOCIAL SCIENCE }\end{array}$ & $\begin{array}{r}\text { https://dinastipub.org/DIJEMSS } \\
\text { editor@dinastipub.org } \\
08117401455 @\end{array}$ \\
\hline
\end{tabular}

\title{
THE INFLUENCE OF MEDICAL TEAM INTERPERSONAL COMMUNICATION ON PATIENT SATISFACTION (SURVEY OF COVID 19 PATIENTS IN DKI JAKARTA)
}

\author{
Nuryani Nuryani ${ }^{1}$, Siti Hamidah ${ }^{2}$, Mustofa Mustofa $^{3}$ \\ ${ }^{1)}$ Universitas Persada Indonesia YAI, Jakarta, yaninur2000@yahoo.com \\ ${ }^{2}$ Universitas Persada Indonesia YAI, Jakarta, sitihamidah.yai@gmail.com \\ ${ }^{3)}$ Universitas Persada Indonesia YAI, Jakarta, moes_tofa@yahoo.com
}

\section{Corresponding Author: Nuryani}

\begin{abstract}
The Covid 19 pandemic is still growing, people must remind each other to comply with health protocols and government appeals so that there will not be a surge. Patients who are contaminated with Covid-19 usually require a medical team to communicate about the effects they are feeling. Interpersonal communication that exists between the medical team and the patient must be effective. This case is to determine the effect of interpersonal communication between the medical team and patients on the level of patient satisfaction. The correlation results obtained are 0.704 , which means that there is a strong relationship between interpersonal communication on patient satisfaction and the results of hypothesis testing indicate that there is an influence between interpersonal communication of the medical team and patients on the satisfaction of patients with Covid 19.
\end{abstract}

Keyword: Interpersonal Communication, Patient Satisfaction, Social Penetrations, Covid-19.

\section{INTRODUCTION}

Until now, Covid-19 is still a scary virus, in Indonesia and even in the world and there have been many deaths due to contracting Covid-19. Currently, the spread from human to human has become the main source of transmission so that the spread of this virus occurs very aggressively. Transmission of this disease occurs from positive Covid 19 patients through droplets that come out when coughing and sneezing (Han Y, 2020). However, it is estimated that this virus spreads from people who are asymptomatic but the test results show a positive Covid-19, besides that it has been studied that this virus can live in aerosols (generated through a nebulizer for at least three hours) (Susilo, et al, 2020).

The determination of the Covid-19 diagnosis examination case is carried out using a PCR (Polymerase Chain Reaction) examination, which is widely known as SWAB. Giving symptomatic drugs according to the symptoms that appear and supportive therapists to support other treatments and increase endurance (Susilo et al, 2020). The best way to prevent 
disease is to break the chain of the spread of Covid-19 through self-isolation, early detection, and basic protection, namely protecting yourself and others by washing your hands frequently with running water with soap or by using a hand sanitizer, wearing a mask and not touching. the face area before washing hands and applying good coughing and sneezing etiquette (Directorate General of P2PK Kemkes RI, 2020).

But for Patients who are infected with Covid 19 who have moderate and severe symptoms are expected to immediately go to the nearest hospital for help. Sometimes Covid sufferers are afraid to go to the hospital because they lack understanding of Covid 19. Covid 19 sufferers who have moderate and mild symptoms will be examined specifically and get special treatment to get well soon, different patients who are not symptomatic can do independent isolation without having to go to the hospital.

However, with the increasing progress of medical science, it can be seen from the emergence of various increasingly sophisticated medical support tools resulting in reduced interpersonal communication between the medical team and patients. The sophistication of medical devices seems to have answered the patient's curiosity about the various diseases they are experiencing so that interpersonal communication that should be well established between the medical team and the patient will automatically decrease (Situmeang and Situmeang, 2018)

Effective interpersonal communication is one of the important components in the patient's recovery process that must be maintained by the medical team. Doctors and nurses need to maintain good relationships and cooperation with patients because doctors and nurses are the closest people who can understand the problems experienced by patients comprehensively so that health services can be carried out comprehensively (Roganda et al., 2015). This is what doctors and patients must understand in dealing with Covid 19 so that patients feel the motivation of the medical team to recover quickly.

In May 2021, Covid 19 sufferers increased in various regions throughout Indonesia, many regions began to implement a lockdown to break the chain of the spread of Covid 19. However, the public is still given education so that they understand if they are indicated as positive for Covid 19 with no symptoms, they must self-isolate so that do not infect others. However, if you have symptoms, seek medical attention immediately. However, because Covid 19 is very easily transmitted from one person to another, sometimes the examination is carried out without talking much but rather to direct action. This makes patients feel less satisfied because they do not get complete information from the examining doctor.

The objectives of this research are: the effect of the medical team's interpersonal communication on the satisfaction of Covid 19 patients.

\section{LITERATURE REVIEW}

\section{Social Penetrations Theory}

Social penetration exists to identify the process of increasing disclosure and intimacy in a relationship and presents a formative theory in the history of the theory of relationships. 
According to Atlman and Taylor in Littlejohn (2009), there are four stages of relationship development, namely: Orientation consists of communication not with certain people, where someone only discloses very general information. If this stage is beneficial to relationship actors, they will move to the next stage, exploratory affective exchange, a movement that leads to a deeper level of disclosure taking place. The third stage, affective exchange, focuses on feelings of criticism and evaluation at a deeper level. This stage will not be entered unless they receive substantial benefits that match the costs in the previous stage. Finally, a balanced exchange is high in closeness and allows them to predict each other's favorable response actions.

Initially, social penetration theory was important in focusing our attention on relationship development as a communication process. This can be incorporated into actual relationship experiences in everyday life. The idea that we move from the general to the private in a straight line now seems very naive. Relationships develop in a variety of ways, often moving back and forth from sharing to personal. Social penetration theory is a circular and dialectical process. It is called rotating because this process works in a back and forth cycle and is called dialectical because it involves an inexhaustible arrangement of pressure between the public and the private. (Littlejohn, 2009).

\section{Interpersonal Communication}

Interpersonal communication has the potential to influence or persuade others. As the most complete and most perfect communication, interpersonal communication plays an important role at any time, as long as humans still have emotions. This face-to-face communication makes people feel more familiar with each other. (Mulyana, 2008). Interpersonal communication includes persuasion. Interpersonal communication plays a role in changing and developing each other. Through interactions in communication, the parties involved in communication can inspire each other, encourage, and encourage each other to change thoughts, feelings, and attitudes by the topic being discussed together (Effendy, 2002).

\section{Patient Satisfaction}

Patient satisfaction is a reflection of the quality of health services they receive. The quality of health services refers to the level of perfection of health services in creating a sense of satisfaction in each patient. The more perfect the satisfaction, the better the quality of health services. However, the relatively good quality of service may not necessarily satisfy the patient. In general, patients cannot assess technical competence, so they judge service quality from non-technical characteristics or interpersonal relationships and service comfort. According to the results of the study, it was found that there were differences in dimensions, namely: For users of health services, the quality of health services was more related to dimensions, namely: responsiveness of officers to meet patient needs, smooth communication between officers and patients.

\section{RESEARCH METHOD}


This study using a positivism research paradigm, using a quantitative research approach, the nature of explanatory research, and research methods using surveys. This study uses a population taken from the patient of Jakarta. saying that the largest number of cases contributing areas came from Jakarta, and took a sample in this study of 30 respondents, this is by the opinion of Gay \& Dichl, the sample size for correlation research at least 30 people, using non-probability sampling with accidental sampling technique. (Purwatiningsih and Situmeang).

\section{RESULTS AND DISCUSSION}

Based on the results of the validity test on the instrument from the Interpersonal Communications variable, it was found that the entire instrument statement of the $\mathrm{X}$ variable, which consisted of 15 questions with 30 samples, was declared valid. Determination of validity is determined by $r$ arithmetic $r$ table ( $r$ table 0.361 for the count $n=30$ ).

\section{Table.1}

\begin{tabular}{llrrr}
\multicolumn{5}{c}{ Case Processing Summary } \\
& & N & \multicolumn{1}{c}{$\%$} \\
\hline \multirow{2}{*}{ Cases } & Valid & 30 & 100.0 \\
\cline { 2 - 4 } & Excluded & 0 & .0 \\
\cline { 2 - 4 } & Total & 30 & 100.0 \\
\hline
\end{tabular}

a. Listwise deletion based on all variables in the procedure.

As for the level of reliability of the instrument with the number of respondents as many as 30 respondents, and with the statement instrument as many as 15 items, Cronbach's Alpha value of 0.796 was obtained so that the instrument was declared to have a high level of reliability or very reliable because it was above 0.60 .

Table.2

Reliability Statistics

\begin{tabular}{|c|c|}
\hline $\begin{array}{c}\text { Cronbach's } \\
\text { Alpha }\end{array}$ & $\mathrm{N}$ of Items \\
\hline .796 & 15 \\
\hline
\end{tabular}

Based on the results of the validity test on the instrument of patient satisfaction variables, it was found that the entire instrument statement of variable $\mathrm{Y}$, which consisted of 16 questions with 30 samples, was declared valid. Determination of validity is determined by $\mathrm{r}$ arithmetic $\mathrm{r}$ table ( $\mathrm{r}$ table 0.361 for the count $\mathrm{n}=30$ ).

Table.3

Case Processing Summary

\begin{tabular}{cc} 
N & $\%$ \\
\hline
\end{tabular}




\begin{tabular}{llr|r}
\hline Cases & Valid & 30 & 100.0 \\
\cline { 2 - 4 } & Excluded & 0 & .0 \\
\cline { 2 - 4 } & Total & 30 & 100.0 \\
\hline
\end{tabular}

a. Listwise deletion based on all variables in the

The level of procedure.

instrument from the

reliability of the variable Y: patient satisfaction, with several respondents as many as 30 people and with several instruments as many as 16 items, Cronbach's Alpha value was obtained at 0.778 so that the instrument was stated to have a high level of reliability or very reliable.

Table.4

\begin{tabular}{|c|c|}
\hline \multicolumn{2}{|c|}{ Reliability Statistics } \\
\hline Cronbach's Alpha & $\begin{array}{c}\mathbf{N} \\
\text { of Items }\end{array}$ \\
\hline .778 & 16 \\
\hline
\end{tabular}

\section{Simple Correlation Test}

A correlation test was conducted to determine the relationship between Interpersonal Communications on patient satisfaction. with the Spearman Rank formula to determine the correlation coefficient between the $\mathrm{X}$ variable and the $\mathrm{Y}$ variable. Here are the results of the correlation test calculation:

\section{Table.5}

\section{Correlation Test Calculation Results Table}

Correlations

\begin{tabular}{|c|c|c|c|}
\hline & & $\begin{array}{c}\text { Interpersonal } \\
\text { Communications }\end{array}$ & $\begin{array}{c}\text { Patient } \\
\text { Satisfactions }\end{array}$ \\
\hline \multirow{3}{*}{$\begin{array}{l}\text { Interpersonal } \\
\text { Communications }\end{array}$} & Pearson Correlation & 1 & $.704^{*}$ \\
\hline & Sig. (2-tailed) & & .000 \\
\hline & $\mathrm{N}$ & 30 & 30 \\
\hline \multirow[t]{3}{*}{ Patient Satisfaction } & Pearson Correlation & $.704^{*}$ & 1 \\
\hline & Sig. (2-tailed) & .000 & \\
\hline & $\mathrm{N}$ & 30 & 30 \\
\hline
\end{tabular}

**. Correlation is significant at the 0.01 level (2-tailed).

\section{Source: SPSS 26 Questionnaire Processed Data}

Based on the table above, it is known that the correlation coefficient $r=0.704$, so it can be interpreted that this value has a very strong relationship because it is between the interpretation value of $0.600-0,799$. So it can be concluded that there is a strong relationship between Variable X: Interpersonal Communication and Variable Y: Patient Satisfaction. 


\section{Simple Linear Regression Test}

A regression test is performed to predict how high the value of the dependent variable $(\mathrm{Y})$ is when the independent variable $(\mathrm{X})$ is varied.

Table.6

Table of Regression Calculation Results

Coefficients

\begin{tabular}{|c|c|c|c|c|c|c|}
\hline \multirow{2}{*}{\multicolumn{2}{|c|}{ Model }} & \multicolumn{2}{|c|}{$\begin{array}{l}\text { Unstandardized } \\
\text { Coefficients }\end{array}$} & \multirow{2}{*}{$\begin{array}{c}\text { Standardized } \\
\text { Coefficients } \\
\text { Beta }\end{array}$} & \multirow[b]{2}{*}{$\mathbf{T}$} & \multirow[b]{2}{*}{ Sig. } \\
\hline & & B & Std. Error & & & \\
\hline \multirow[t]{2}{*}{1} & (Constant) & 11.806 & 9.536 & & 1.179 & .150 \\
\hline & $\begin{array}{l}\text { Interpersonal } \\
\text { Communication }\end{array}$ & 1.129 & .411 & .777 & 11.169 & .000 \\
\hline
\end{tabular}

a. Dependent Variable: Patient Satisfaction.

Processed Data of 26 SPSS Questionnaire Results

$$
Y=a+b X
$$

Information:

$Y^{\prime} \quad$ : Value that predictable

: Constant or if the price $\mathrm{X}=0$

: Regression coefficient

: Score independent variable

Then:

$$
Y=11.806+1,129 X
$$

The equation can be interpreted as follows:

a The value of constant (a) is 11.806 , meaning that the consistent value of the $\mathrm{Y}$ variable or Patient Satisfaction is 11.806 .

b. The regression coefficient Interpersonal Communication obtained the result of 1,129, which means that with every $1 \%$ addition of the value of the variable Interpersonal Communications, then the value of the Patient satisfaction variable will increase by 1.129 .

c. The regression coefficient figure obtained a positive value, it can be understood that the direction of the influence of Interpersonal Communication on Patient Satisfaction is positive.

\section{Coefficient of Determination Test}

Calculation of the amount of contribution given by the variable Interpersonal Communications on the Patient Satisfaction variable can be seen in the following table: 
Table.7

\begin{tabular}{|c|c|c|c|c|}
\hline \multicolumn{5}{|c|}{ Model Summary } \\
\hline Model & $\mathbf{R}$ & R Square & $\begin{array}{l}\text { Adjusted R } \\
\text { Square }\end{array}$ & $\begin{array}{l}\text { Std. Error of the } \\
\text { Estimate }\end{array}$ \\
\hline 1 & $.734 a$ & .566 & .561 & 10.28682 \\
\hline
\end{tabular}

To find out the magnitude of the contribution of the influence of Interpersonal Communication on Patient Satisfaction, the coefficient of determination is calculated, by squaring the correlation results, then multiplied by $100 \%$, as follows:

$K d=r^{2} \times 100 \%$

Information:

$\mathrm{Kd} \quad=$ Coefficient of determination

$\mathrm{r} \quad=$ Correlation coefficient

$$
\begin{aligned}
\mathrm{Kd} & =0.734^{2} \times 100 \% \\
& =0.538 \times 100 \% \\
& =53,8 \%
\end{aligned}
$$

Based on the calculation of the determination results, it can be seen that the correlation value $(r)=0.734$ and the value of $\mathrm{R}$ Square (squaring of the correlation value), which is $0.538=53,8 \%$. So it can be concluded that $53,8 \%$ of patient satisfaction is influenced by Interpersonal Communication and 46,2 \% influenced by other factors not examined.

\section{Hypothesis testing}

Hypothesis testing was carried out to find out whether Interpersonal Communications significant effect on patient satisfaction. The basis for decision making is to compare $t$ count with $\mathrm{t}$ table, which is as follows:

a. If $t$ count $<\mathrm{t}$ table, then Ho is accepted and Ha is rejected.

b. If $\mathrm{t}$ count $>\mathrm{t}$ table, then Ho is rejected and $\mathrm{Ha}$ is accepted.

Table.8

\begin{tabular}{|c|c|c|c|c|c|c|}
\hline & \multirow[b]{2}{*}{ Model } & \multicolumn{2}{|c|}{ Unstandardized Coefficients } & \multirow{2}{*}{$\begin{array}{c}\text { Standardized } \\
\text { Coefficients } \\
\text { Beta }\end{array}$} & \multirow[b]{2}{*}{$\mathbf{T}$} & \multirow[b]{2}{*}{ Sig. } \\
\hline & & B & Std. Error & & & \\
\hline 1 & (Constant) & 12,979 & 9,602 & & 1.225 & .180 \\
\hline & $\begin{array}{c}\text { Interpersonal } \\
\text { Communications }\end{array}$ & 1.367 & -121 & .820 & 11,313 & .000 \\
\hline
\end{tabular}

Table of Hypothesis Calculation Results Coefficients Standardized 
a.

Dependent Variable: Patient Satisfaction

Processed Data of 26 SPSS Questionnaire Results

Determination of significant conclusions by comparing $t$ count with $t$ table, namely the determination of the level of signification. From the $t$ table the value is determined at a significant level of 0.10 and $\mathrm{df}=\mathrm{n}-2$, ie $30-2=28$. Thus the $\mathrm{t}$ table value is 0.683335 . The basis of decision making is to compare $t$ count with $\mathrm{t}$ table:

1. If $\mathrm{t}$ count $>\mathrm{t}$ table, then $\mathrm{Ho}$ is rejected and $\mathrm{Ha}$ is accepted (big influence)

2. If $\mathrm{t}$ count $<\mathrm{t}$ table, then Ho is accepted and $\mathrm{Ha}$ is rejected (no big effect)

Determination of significant conclusions by comparing $t$ count 11.313 with t table, namely the determination of the level of signification. From the table, the value is determined at a significant level of 0.10 and $\mathrm{df}=\mathrm{n}-2$, namely $30-2=28$. Thus, the table is 0.683335 . Thus, the $\mathrm{t}$ count is greater than the $\mathrm{t}$ table, which means $\mathrm{Ha}$ is accepted and $\mathrm{H} 0$ is rejected. This means that Interpersonal Communications has a big influence on patient satisfaction.

\section{CONCLUSION}

\section{Conclusion}

Based on the results of research and discussion, it can be concluded as follows:

1. Overall instrument of variable $\mathrm{X}$ : Interpersonal Communication and variable Y: Patient Satisfactions is very reliable so that the research instrument is very reliable and can be generalized to the entire population throughout Indonesia.

2. There is a relationship that very strong between Interpersonal Communications with the patient satisfaction in implementing the Health protocol during the pandemic and complying with the appeal from the government with a correlation coefficient rcount of 0.704 .

3. Interpersonal Communications have a big or significant effect on people's behavior $72.3 \%$ of community behavior is influenced by activities Interpersonal Communications what people often do. With activities Interpersonal Communications what the community is doing about complying with Health protocols and government appeals during this pandemic.

\section{Suggestion}

The medical team and patients should help each other to get cured, especially at this time many patients need medical help but patients must also respect and follow the advice given by the medical team to get well soon from the patient's illness. Good cooperation between the medical team and patients and their families are very much needed in resolving the Covid-19 pandemic in Indonesia.

\section{REFERENCE}

Effendi, Onong Uchjana. (2002) Communication Science Theory and Practice. Bandung: Rosdakarya Youth. 
Han Y, Yang H (2020) The Transmission and Diagnosis Of 2019 Novel Corona Virus Infection Disease (Covid 19) Chinese perspective. J Medvirol. Published Online March 6

Little John Sw. Karen Af. 2009. Communication Theory. Jakarta: Salemba Humanika.

Purwatiningsih, Sri Desti. Situmeang, Ilona Vicenovie Oisina. (2021). Campaign Effectinevess On Communications Engineering Behavior In Use Of Sinovac Covid19 Vaccine. Turkish Journal Of Computer And Mathematical Educations. Vol 12 No 04 (2021): 1538-1545.

Roganda Dp, Dkk. 2015. Patterns of Therapeutic Interpersonal Communication of Doctors to Children Patients. Jakarta: Journal of Business and Communication Bisnisocio. Issn 2356-4385 Pages 183-193.

Situmeang Ilona Vicenovie Oisina, Situmeang Ivonne Ruth Vitamaya Oisi. (2018). Correlation of Effective Interpersonal Communication and Quality of Service of the Medical Team on Patient Satisfaction (Survey of Patients at Claudia Bagan Batu Hospital, Riau).

Supartiningsih Solichah. (2017). Hospital Patient Satisfaction Service Quality: Cases in Outpatients. Journal of Medicoeticolegal and Hospital Management, 6 (1): 9-15, April $2017 \quad$ Website: Http://Journal.Umy.Ac.Id/Index.Php/Mrs Doi: 10.18196/Jmmr.6122

Susilo Adityo, Rumendecm, et al (2020) Corona Virus Disease 2019: Review of Current Literature, Indonesian Journal of Internal Medicine. Volume 17 No. 1 March 2020.

Who (2020). Corona Virus (Covid 19), Outbreak,Https://Www.Who.Int/Emergencies/Diseases/Novel-Coronavirus-2019 Who(2020)Coronavirusdisease(Covid-19)Situationreport-114,May13,2020 